\title{
Impact of pH Variation on Coag-flocculation Behaviour of Chitin Derived Coag-flocculant in Coal Washery Effluent Medium
}

\author{
M.C. Menkiti * and O.D. Onukwuli \\ Department of Chemical Engineering, Nnamdi Azikiwe University Awka, Nigeria. \\ *Corresponding author : cmenkiti@yahoo.com
}

\begin{abstract}
This work investigates the influence of $p H$ variation on coag-flocculation kinetics and performance of Chitin Derived Coag-flocculant $(C D C)$ in removal of Suspended and Dissolved Particles (SDP) from Coal washery effluent (CWE) medium. Key parameters such as rate constant $K_{m}$, half life $\tau_{1 / 2}$, and $\mathrm{pH}$ etc. were investigated. The best coag-flocculation performance is recorded at $K_{m}$, of $0.007 \mathrm{l} / \mathrm{mg} . \mathrm{min}, \tau_{1 / 2}$, of $0.0362 \mathrm{~min}$, pH of 8, dosage of $100 \mathrm{mg} / \mathrm{l}$ and efficiency $E(\%)$ of 99.933. Minimum efficiency (\%) $>94.00$ was achieved at 30 minutes of coagflocculation, establishing CDC as an effective water treatment agent at the conditions of the experiment.
\end{abstract}

Keywords: Coal effluent, coag-flocculation, coagulation, chitin, chitosan

\section{INTRODUCTION}

The biosphere is increasingly exposed to pollution threats in spite of the global efforts to protect it. Anthropogenic activities are the significant and dominant sources of these threats. The growing human needs and ceaseless drive to satisfy them have led to the production of varying forms of harmful wastes that ultimately rest in our aqua systems. The implication is that much of the water cannot be used without a form of treatment. This situation brings to the fore the needed impetus to focus on challenges inherent in hydro management, especially in developing countries where discharge of effluent such as CWE is common. 
CWE, emanating from washery unit of coal mining operation depicts elevated concentrations of organic and inorganic loads [1,2]. Such loads include kaolinite, illite, muscovite, quartz, bacteria, colloids, virus, color, nitrogen, aromatics, sulphur, phosphorus etc. These contaminants make CWE a significant environmental pollutant, and thus subject to removal during treatment processes such as coag-flocculation $[3,4]$.

Coag-flocculation as a treatment procedure has existed for years. The procedure is accomplished by the addition of ions having opposite charge to that of the particles. Typically, the ion species are from metal salts, capable of destabilizing stable colloids in suspension, such that they can agglomerate into settleable floc [5,6]. The application of $\mathrm{Al}$ and Fe salts are well established in the practice, though they are linked with health and cost challenges [6].

Attempts to confront these challenges highlight the persistent search for new substitutes to metal salts and the current drive to improve the efficiency of existing substitutes [7,8,9]. Among the established existing substitutes is chitin derived coag-flocculant (CDC), popularly known as chitosan. CDC is obtained from chitin of crustaceans such as crawfish and crab. CDC, a polycationic, biodegradable, non-toxic and high molecular weight linear copolymer of glucosamine and $\mathrm{N}$-acetyl glucoseamine, is soluble and positively charged in acid media and may therefore be used as eco-friendly coag-flocculant $[10,11]$.

CDC has been widely used as an effective coag-flocculant for a wide variety of suspended solids in various food and fish processing industries [12,13,14] and suspension containing mineral colloids in water $[11,15,16,17,18]$. The reactivity of CDC during coag-flocculation of suspended and dissolved particles (SDP) results from several mechanisms, including electrostatic attraction, sorption and bridging. The contribution of each mechanism depends on the $\mathrm{pH}$ of the suspension.

In this presnt study, the influence of CDC dosage and $\mathrm{CWE} \mathrm{pH}$ on the kinetics and coagflocculation efficiency of the process were examined. It is expected that the kinetics results will enrich the existing kinetic data towards development of more efficient and robust coagflocculation units that ensure the conservation of the environment.

\section{THEORY.}

The rate of successful collision between particles of sizes $i$ and $j$ to form particle of size $k$ is [19]:

$$
\frac{d n_{k}}{d t}=\frac{1}{2} \sum_{i+j=k} \beta_{B R}(i, j) n_{i} n_{j}-\sum_{i=1}^{\alpha} \beta_{B R}(i, k) n_{i} n_{k}
$$

where $\beta_{\mathrm{BR}(\mathrm{i}, \mathrm{j})}$ is Brownian aggregation factor for flocculation transport mechanism, $\mathrm{n}_{\mathrm{i}} \mathrm{n}_{\mathrm{j}}$ is particle aggregation concentration for particles of size $\mathrm{i}$ and $\mathrm{j}$, respectively. 
It has been established that $[19,20]$ :

$$
\beta_{B R}=\frac{8}{3} \varepsilon_{p} \frac{K_{B} T}{\eta}
$$

where $\mathrm{K}_{\mathrm{B}}, \mathrm{T}, \eta, \varepsilon_{\mathrm{p}}$ are Boltzmann constant, temperature, viscosity and collision efficiency factor, respectively.

It can be shown that:

$$
\begin{aligned}
\frac{1}{2} \beta_{B R} & =\varepsilon_{p} K_{R}=K_{m} \\
-\frac{d N_{t}}{d t} & =K_{m} N_{t}^{\alpha}
\end{aligned}
$$

$\mathrm{K}_{\mathrm{R}}$ is defined as Von Smoluchowski rate constant for rapid coagulation. $\mathrm{K}_{\mathrm{m}}$ is Menkonu coagflocculation rate constant accounting for Brownian coag-flocculation transport of destabilized particles at $\alpha^{\text {th }}$ order. $\mathrm{N}_{\mathrm{t}}$ is the concentration of SDP at time, $\mathrm{t}[9,21,22]$.

Graphical representation of linear form of equation 5 at $\alpha=2$ provides $K_{m}$ from the slope of equation below:

$$
\frac{1}{N}=K_{m} t+\frac{1}{N_{0}}
$$

where $\mathrm{N}_{0}$ is upper limit of $\mathrm{N}_{\mathrm{t}}$ at $\mathrm{t}>0 . \mathrm{N}_{0}$ is $\mathrm{N}_{\mathrm{t}}$ at $\mathrm{t}=0$.

Equation 6 can be solved to obtain coag-flocculation period, $\tau_{1 / 2}$

$$
\tau_{1 / 2}=\left(0.5 N_{0} K_{m}\right)^{-1}
$$

Equation 2 solved exactly results in generic expression for microscopic aggregation

$$
\frac{N_{m(t)}}{N_{0}}=\frac{\left[1 / \tau_{1 / 2}\right]^{m-1}}{\left[1+\frac{t}{\tau_{1 / 2}}\right]^{m+1}}
$$

$\mathrm{m}=1$ (monomer), $\mathrm{m}=2$ (doublet), $\mathrm{m}=3$ (triplet)

Efficiency of coag-flocculation is expressed as:

$$
E(\%)=\left[\frac{N_{0}-N_{t}}{N_{0}}\right] 100
$$




\section{MATERIALS AND METHODS}

\subsection{Materials Collection, Preparation and Characterization}

\subsubsection{Coal washery effluent}

The effluent was taken from a coal mine located in Enugu, Enugu State, Nigeria. The characterization of the effluent presented in Table 1 were determined based on standard method [23].

\subsubsection{Crab shell sample}

Crab Shell samples (precursor to CDC) were sourced from Nsugbe, Anambra State, Nigeria. CDC was prepared according to procedure reported by Fernandez-Kim [24]. The characteristics of the sample on the bases of AOAC standard method [25] are presented in Table 2.

Table 1: Characteristics of coal washery effluent

\begin{tabular}{ll}
\hline Parameters & Values \\
\hline $\mathrm{pH}$ & 2.5200 \\
Turbidity (NTU) & 5387.0000 \\
Total hardness(mg/l) & 358.0000 \\
Ca hardness (mg/l) & 306.0000 \\
$\mathrm{Mg}$ hardness (mg/l) & 52.0000 \\
$\left.\mathrm{Ca}^{2+(} \mathrm{mg} / \mathrm{l}\right)$ & 122.4000 \\
$\left.\mathrm{Mg}^{2+(} \mathrm{mg} / \mathrm{l}\right)$ & 15.6000 \\
$\left.\mathrm{Fe}^{2+(} \mathrm{mg} / \mathrm{l}\right)$ & 0.2500 \\
$\left.\mathrm{SO}_{4}{ }^{2-(} \mathrm{mg} / \mathrm{l}\right)$ & 72.0000 \\
$\left.\mathrm{NO}_{3}{ }^{2-(} \mathrm{mg} / \mathrm{l}\right)$ & Nil \\
$\mathrm{Cl}^{-}(\mathrm{mg} / \mathrm{l})$ & 184.3400 \\
$\mathrm{E} . \mathrm{cond}\left(\mu \mathrm{m} / \mathrm{m}^{2}\right)$ & 805.2000 \\
$\mathrm{TDS}(\mathrm{mg} / \mathrm{l})$ & 450.9120 \\
$\mathrm{TSS}(\mathrm{mg} / \mathrm{l})$ & 109.6000 \\
$\mathrm{~T} . \mathrm{Coliform}$ & Nil \\
$\mathrm{Plate} \mathrm{Count}$ & $4.0000 \mathrm{~s}$ \\
$\mathrm{E}-\mathrm{Coli}$ & Nil \\
$\mathrm{BOD}_{5}$ & 1001.0110 \\
\hline
\end{tabular}




\begin{tabular}{ll} 
Table 2 : Characteristics of coag-flocculant \\
\hline Parameter & CDC \\
\hline Moisture content (\%) & 9.7700 \\
Ash content (\%) & 2.6800 \\
Lipid content (\%) & 27.1800 \\
Crude protein(\%) & 44.3800 \\
Carbohydrate(\%) & 16.2600 \\
\hline
\end{tabular}

\subsection{Coag-flocculation Experiments}

Experiments were conducted using conventional jar test apparatus. Appropriate dosage of CDC in the range $100-500 \mathrm{mg} / \mathrm{l}$ was added directly to $200 \mathrm{ml}$ of CWE. The suspension, tuned to $\mathrm{pH}$ range 2-10 by application of $\mathrm{H}_{2} \mathrm{SO}_{4} / \mathrm{NaOH}$ was subjected to 2 minutes of rapid mixing (250rpm),20minutes of slow mixing (20rpm) and followed by 30 minutes of settling. During settling, samples were withdrawn from $2 \mathrm{~cm}$ depth and turbidity (converted to SDP in $\mathrm{mg} / \mathrm{l}$ ) changes measured for kinetic analysis. .

\section{RESULTS AND DISCUSSION}

The results of the investigation on the coag-flocculation of CWE by CDC are presented and discussed sequentially as presented below:

\subsection{Coag-Flocculation Kinetics}

Presented in tables 3-7 are functional kinetics parameters obtained for the coag-flocculation of CDC in CWE at $\mathrm{pH} 2,4,6,8,10$ for 100, 200, 300, 400,500mg/l CDC dosages. Linear regression coefficient $\left(\mathrm{R}^{2}\right)$ was employed in evaluation of the level of accuracy of fit of the experimental data on the considered model equation 5. Tables 3-7 indicate that data (with majority of $R^{2}>0.9$ ) were significantly described by the linearized form of equation 4 expressed as equation 5 .

$\mathrm{K}_{\mathrm{m}}$, determined from the slope of equation 5 is a vital factor that determines the rate of reaction. Higher $\mathrm{K}_{\mathrm{m}}$ translates to higher rate of coag-flocculation. $\mathrm{K}_{\mathrm{m}}$ is evaluated by fitting the experimental data on the plot of $(1 / \mathrm{N})$ or $(1 / \mathrm{SDP})$ against time as can be deduced from equation 5. Representative results for the various dosages and $\mathrm{pH}$ as displayed in tables 3-7 are graphically depicted in Figure 1. It should be noted that the trends for the various dosages and $\mathrm{Ph}$ ( not shown) are identical. $\mathrm{K}_{\mathrm{m}}\left(=0.5 \beta_{\mathrm{BR}}\right)$ as expressed in equation 3 and shown in tables 3-7 recorded maximum and minimum values of 0.007 and $3 \times 10^{-5} 1 / \mathrm{mg}$.min, respectively. It can be observed that least values of $\mathrm{K}_{\mathrm{m}}$ were obtained at $\mathrm{pH}$ 2. One possible explanation is the likelihood of excess protonation of the particles, leading to partial or total charge reversal. The 
consequence is the prevalence of repulsion of the particle and the attendant poor performance observed in $\mathrm{pH} 2$. From $\mathrm{pH} 4$ to alkaline condition, $\mathrm{CDC}$ can perform satisfactorily but to a different extent [26,27]. This explains why high and low values of $\mathrm{K}_{\mathrm{m}}$ were obtained at both acidic and alkaline conditions of CWE.

Another two essential parameters are $\varepsilon_{\mathrm{p}}$ and $\mathrm{K}_{\mathrm{R}}$. From equations 2 and $3, \varepsilon_{\mathrm{p}}$ and $\mathrm{K}_{\mathrm{R}}$ could be evaluated, respectively. It can be deduced from equation 2 that $K_{R}$ is a function of $K_{B}$, temperature and viscosity. Mathematically, it can be expressed as $K_{R}=f n(T, \eta)$. Values of $K_{R}$ obtained from Tables 3-7 indicate there is no significant practical variation among the values. This trend follows minimal variation in the values of temperature and viscosity. At approximately constant $\mathrm{K}_{\mathrm{R}}, \varepsilon_{\mathrm{p}}$ relates directly to $2 \mathrm{~K}_{\mathrm{m}}=\beta_{\mathrm{BR}}$ (equation 3 ). Thus, high $\varepsilon_{\mathrm{p}}$ results in high kinetic energy providing particle momentum to ensure the overcoming of the electrostatic repulsive forces by the coag-flocculating particles. It should be noted that high repulsive forces translate to high zeta potential, which in this present study is relatively high at $\mathrm{pH} 2$. From theoretical point of view, $\tau_{1 / 2}, \mathrm{~K}_{\mathrm{R}}$ and $\varepsilon_{\mathrm{p}}$ are believed to be effectiveness factor, understood to be accounting for the coagulation efficiency before the commencement of flocculation.

The coag-flocculation period, $\tau_{1 / 2}$, is evaluated from equation 6 . It can be inferred that $\tau_{1 / 2}$, $=\mathrm{fn}\left(\mathrm{N}_{0}\right)$. It implies that the higher the $\mathrm{N}_{0}$, the lesser the $\tau_{1 / 2}$. This accounts for high settling rate prevalent among waters with high initial turbidity load. On a broad base, the discrepancies noted in the results of the functional parameters are due to unattainable assumption that mixing of CWE particles and CDC throughout the dispersion is $100 \%$ efficient before aggregation occurs [22, 28, 29]. Second account is the interplay between Van der Wall's forces and the hydro dynamic interactions which typically alters the theoretical predicted values by a factor of \pm 2 .

Table 3 : Coag-flocculation kinetic parameters of CDC in CWE at varying pH and $100 \mathrm{mg} / \mathrm{l}$ dosage

\begin{tabular}{|c|c|c|c|c|c|}
\hline Parameters & $\mathrm{pH}=2$ & $\mathrm{pH}=4$ & $\mathrm{pH}=6$ & $\mathrm{pH}=8$ & $\mathrm{pH}=10$ \\
\hline$\alpha$ & 2.0000 & 2.0000 & 2.0000 & 2.0000 & 2.0000 \\
\hline $\mathrm{R}^{2}$ & 0.9363 & 0.9574 & 0.9284 & 0.9828 & 0.9268 \\
\hline$K_{m}(l / m g . m i n)$ & 4E- 05 & 0.001 & 0.0009 & 0.0022 & 0.0014 \\
\hline$\beta_{E R}(1 / \mathrm{mg} \cdot \mathrm{min}$ & $8 E-05$ & 0.002 & $1.8 \times 10^{-3}$ & 0.0044 & 0.0028 \\
\hline$K_{R}(l / m i n)$ & $7.1668 \times 10^{-12}$ & $9.4422 \times 10^{-12}$ & $9.4263 \times 10^{-12}$ & $9.7352 \times 10^{-12}$ & $7.5623 \times 10^{-12}$ \\
\hline$s_{p}(1 / m g)$ & $1.1162 \times 10^{7}$ & $2.1181 \times 10^{8}$ & $1.9095 \times 10^{8}$ & $4.5196 \times 10^{8}$ & $3.7025 \times 10^{8}$ \\
\hline$\tau 1 / 2(\mathrm{~min})$ & 2.5368 & 0.0781 & 0.1128 & 0.0461 & 0.0724 \\
\hline$N_{0}(m g / l)$ & 10000.0000 & 322.5806 & 204.0816 & 86.9565 & 476.1905 \\
\hline$(N p)_{0}(/ l)$ & $6.0220 \times 10^{24}$ & $1.9425 \times 10^{23}$ & $1.2289 \times 10^{23}$ & $5.2365 \times 10^{22}$ & $2.8676 \times 10^{23}$ \\
\hline
\end{tabular}


Table 4 : Coag-flocculation kinetic parameters of CDC in CWE at varying $\mathrm{pH}$ and $200 \mathrm{mg} / \mathrm{l}$ dosage

\begin{tabular}{|c|c|c|c|c|c|}
\hline Parameters & $\mathrm{pH}=2$ & $\mathrm{pH}=4$ & $\mathrm{pH}=6$ & $\mathrm{pH}=8$ & $\mathrm{pH}=10$ \\
\hline$\alpha$ & 2.0000 & 2.0000 & 2.0000 & 2.0000 & 2.0000 \\
\hline $\mathrm{R}^{2}$ & 0.7962 & 0.9908 & 0.9129 & 0.9209 & 0.9872 \\
\hline$K_{m}(l / m g \cdot m i n)$ & $3 \mathrm{E}-05$ & 0.0020 & 0.0023 & 0.0024 & 0.0015 \\
\hline$\beta_{E R}(l / m g \cdot \min$ & $6 \mathrm{E}-05$ & 0.004 & 0.4600 & 0.0048 & $3 \times 10^{-3}$ \\
\hline$K_{R}(l / m i n)$ & $1.0992 \times 10^{-11}$ & $1.0474 \times 10^{-11}$ & $8.8758 \times 10^{-12}$ & $9.5713 \times 10^{-12}$ & $7.9004 \times 10^{-12}$ \\
\hline$\varepsilon_{p}(1 / m g)$ & $5.4631 \times 10^{6}$ & $3.8187 \times 10^{7}$ & $5.1826 \times 10^{8}$ & $5.0149 \times 10^{8}$ & $3.7972 \times 10^{8}$ \\
\hline$\pi 1 / 2(\min )$ & 3.3825 & 0.5074 & 0.5074 & 0.0422 & 0.0677 \\
\hline$N_{0}(m g / l)$ & 10000.0000 & 3333.3333 & 285.1142 & 57.4713 & 84.0336 \\
\hline$(N p)_{0}(/ l)$ & $6.0220 \times 10^{24}$ & $2.0073 \times 10^{24}$ & $1.7206 \times 10^{23}$ & $3.4609 \times 10^{22}$ & $1.85663 \times 10^{22}$ \\
\hline
\end{tabular}

Table 5 : Coag-flocculation kinetic parameters of CDC in CWE at varying $\mathrm{pH}$ and $300 \mathrm{mg} / \mathrm{l} \mathrm{dosage}$

\begin{tabular}{|c|c|c|c|c|c|}
\hline $\begin{array}{l}\text { Parameters } \\
\text { Para }\end{array}$ & $\mathrm{pH}=2$ & $\mathrm{pH}=4$ & $\mathrm{pH}=6$ & $\mathrm{pH}=8$ & $\mathrm{pH}=10$ \\
\hline$\alpha$ & 2.0000 & 2.0000 & 2.0000 & 2.0000 & 2.0000 \\
\hline $\mathrm{R}^{2}$ & 0.7970 & 0.8805 & 0.7721 & 0.9349 & 0.9388 \\
\hline$K_{m}(1 / m g \cdot m i n)$ & $3 \mathrm{E}-05$ & 0.0009 & 0.0017 & 0.0019 & 0.0006 \\
\hline$\beta_{B R}(l / m g \cdot m i n$ & $6 \mathrm{E}-05$ & $1.8 \times 10^{-3}$ & $3.4 \times 10^{-3}$ & $3.8 \times 10^{-3}$ & $1.2 \times 10^{-3}$ \\
\hline$K_{K}(l / m i n)$ & $9.8944 \times 10^{-12}$ & $1.0878 \times 10^{-11}$ & $1.0291 \times 10^{-11}$ & $7.8483 \times 10^{-12}$ & $7.9061 \times 10^{-12}$ \\
\hline$s_{p}(1 / m g)$ & $6.0663 \times 10^{6}$ & $1.6546 \times 10^{8}$ & $3.3038 \times 10^{8}$ & $4.8418 \times 10^{8}$ & $1.5178 \times 10^{8}$ \\
\hline $\mathrm{T1}_{1 / 2}(\mathrm{~min})$ & 3.3825 & 0.1128 & 0.0596 & 0.0534 & 0.1691 \\
\hline$N_{0}(m g / l)$ & 50000.0000 & 322.5806 & 2564.1025 & 2500.0000 & 2500.0000 \\
\hline$(N p)_{0}(/ l)$ & $3.0110 \times 10^{25}$ & $1.9426 \times 10^{23}$ & $1.5441 \times 10^{24}$ & $1.5055 \times 10^{24}$ & $1.5055 \times 10^{24}$ \\
\hline
\end{tabular}

Table 6 : Coag-flocculation kinetic parameters of CDC in CWE at varying pH and $400 \mathrm{mg} / \mathrm{l} \mathrm{dosage}$

\begin{tabular}{|c|c|c|c|c|c|}
\hline Parameters & $\mathrm{pH}=2$ & $\mathrm{pH}=4$ & $\mathrm{pH}=6$ & $\mathrm{pH}=8$ & $\mathrm{pH}=10$ \\
\hline$\alpha$ & 2.0000 & 2.0000 & 2.0000 & 2.0000 & 2.0000 \\
\hline $\mathrm{R}^{2}$ & 0.9828 & 0.9576 & 0.9821 & 0.9963 & 0.8194 \\
\hline$K_{m}(l / m g \cdot m i n$ & $4 \mathrm{E}-05$ & 0.0006 & 0.0028 & 0.0010 & 0.0018 \\
\hline$\beta_{E R}(l / m g . m i n$ & $8 \mathrm{E}-05$ & $1.2 \times 10^{-3}$ & $5.6 \times 10^{-3}$ & 0.0020 & $3.6 \times 10^{-3}$ \\
\hline$K_{R}(l / \mathrm{min})$ & $1.0180 \times 10^{-11}$ & $1.0335 \times 10^{-11}$ & $8.7400 \times 10^{-12}$ & $8.5143 \times 10^{-11}$ & $8.5552 \times 10^{-12}$ \\
\hline$s_{p}(1 / m g)$ & $7.8585 \times 10^{6}$ & $1.1610 \times 10^{8}$ & $6.4072 \times 10^{8}$ & $2.3489 \times 10^{8}$ & $4.2079 \times 10^{8}$ \\
\hline
\end{tabular}




\begin{tabular}{|c|c|c|c|c|c|}
\hline$\pi_{1 / 2}(m i n)$ & 2.5368 & 0.1691 & 0.0362 & 0.1014 & 0.05663 \\
\hline$N_{0}(\mathrm{mg} / \mathrm{l})$ & 25000.0000 & 555.5556 & 263.1578 & 88.3333 & 104.1667 \\
\hline$(N p)_{0}(/ D)$ & $1.5055 \times 10^{25}$ & $3.3456 \times 10^{23}$ & $1.5847 \times 10^{23}$ & $5.0183 \times 10^{22}$ & $6.2727 \times 10^{22}$ \\
\hline
\end{tabular}

Table 7 : Coag-flocculation kinetic parameters of CDC in CWE at varying pH and $500 \mathrm{mg} / \mathrm{l} \mathrm{dosage}$

\begin{tabular}{|c|c|c|c|c|c|}
\hline Parameters & $\mathrm{pH}=2$ & $\mathrm{pH}=4$ & $\mathrm{pH}=6$ & $\mathrm{pH}=8$ & $\mathrm{pH}=10$ \\
\hline$\alpha$ & 2.0000 & 2.0000 & 2.0000 & 2.0000 & 2.0000 \\
\hline $\mathrm{R}^{2}$ & 0.9552 & 0.9501 & 0.8531 & 0.9320 & 0.9862 \\
\hline$K_{m}(l / m g . m i n$ & $4 \mathrm{E}-05$ & 0.0006 & 0.0018 & 0.0026 & 0.0070 \\
\hline$\beta_{B R}(1 / \mathrm{mg} \cdot \mathrm{min}$ & $8 \mathrm{E}-05$ & $1.2 \times 10^{-3}$ & $3.6 \times 10^{-3}$ & $5.2 \times 10^{-3}$ & 0.0140 \\
\hline$K_{R}(l / \mathrm{min})$ & $9.4882 \times 10^{-12}$ & $1.089 \times 10^{-11}$ & $1.0188 \times 10^{-11}$ & $1.0155 \times 10^{-11}$ & $9.1790 \times 10^{-12}$ \\
\hline$\varepsilon_{p}(1 / m g)$ & $8 . .4314 \times 10^{6}$ & $1.1894 \times 10^{8}$ & $3.5335 \times 10^{8}$ & $5.1206 \times 10^{8}$ & $15252 \times 10^{9}$ \\
\hline$\pi 1_{2}(m i n)$ & 2.5368 & 0.1690 & 0.0566 & 0.0390 & 0.1449 \\
\hline$N_{0}(m g / l)$ & 12500.0000 & 1428.5714 & 142.8571 & 238.0952 & 212.7659 \\
\hline$(N p)_{0}(/ l)$ & $7.5275 \times 10^{24}$ & $8.6031 \times 10^{22}$ & $8.6031 \times 10^{22}$ & $1.4338 \times 10^{23}$ & $1.2812 \times 10^{23}$ \\
\hline
\end{tabular}

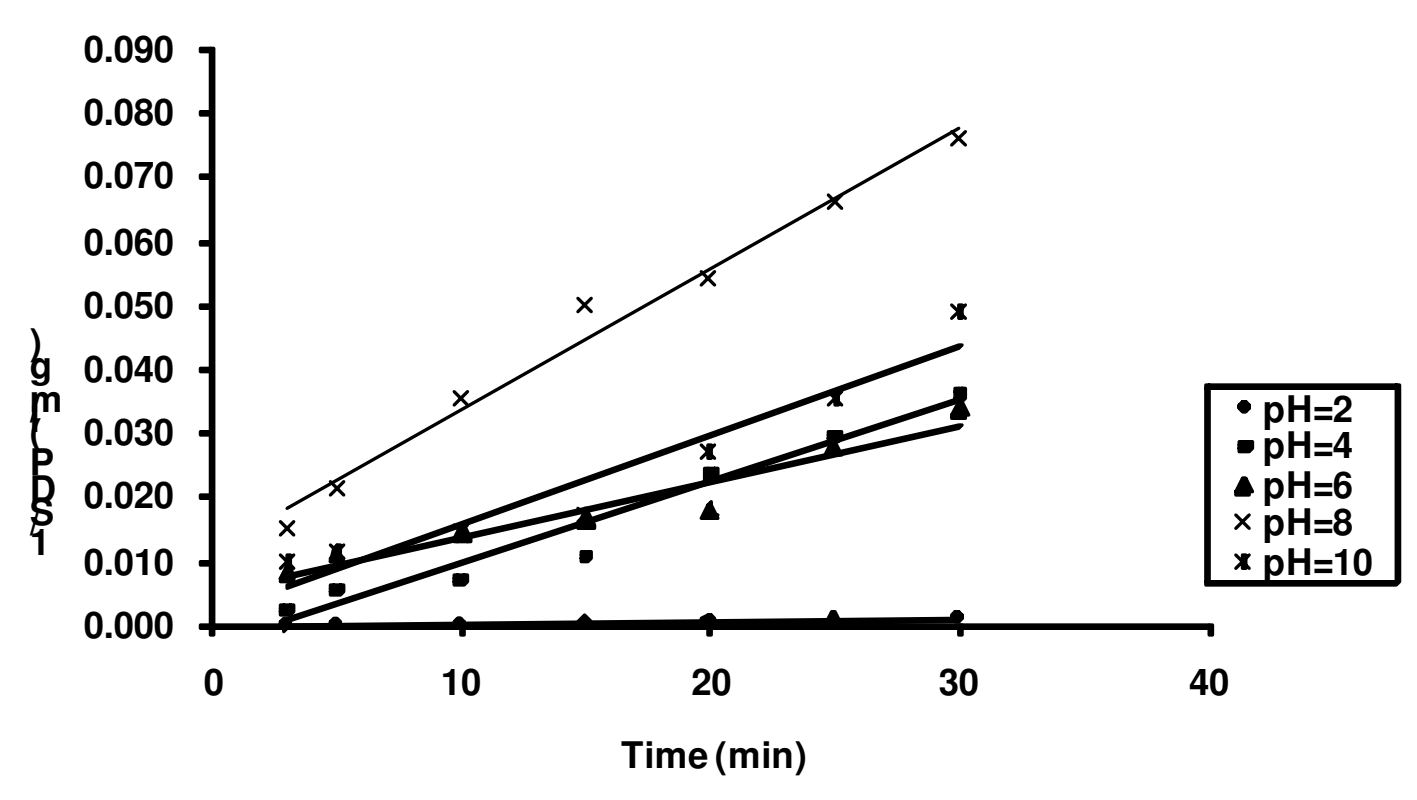

Fig. 1: Kinetic profile of SDP removal from CWE by CDC at 100mg/l 


\subsection{Time Evolution of Cluster Size Distribution.}

The time evolutions of cluster size distribution are presented in the graphical form of number of particles as a function of time. By substituting $\mathrm{K}_{\mathrm{m}}$ from equation 5 into 7 , the particle aggregation at a microscopic levels can be predicted graphically by the interaction of singlets $(\mathrm{m}=1)$, doublets $(\mathrm{m}=2)$ and triplets $(\mathrm{m}=3)$. The singlets, doublets and triplets are composed of single, double and triple monomers, respectively. Representative results are shown in Figures 2 and 3. The perceived difference in the nature of the curves in response of two different $\tau_{1 / 2}$ of 0.0362 and 3.382 minutes are demonstrated as case I and caseII, respectively.

Case I This is shown graphically as Figure 2. In this case, the singlet and total particle sum can be seen to decrease more rapidily. This is evidence of high rate of coag-flocculation supported by low half life. This can be accounted on the bases of sweep-floc or/ and massive instantaneous destabilization of the particles. With prevalent low zeta potential in the fluid, the CDC sweepfloc the particle out of the suspension [30].

Case II This is particle distribution that is associated with coag-flocculation process where there is absence of excessive entrapment and high shear resistance. The dominating aggregation mechanisms are charge neutralization in conjunction with low bridging to ensure moderate speed of coag-flocculation associated with moderate energy barrier in view of gentle nature of the curves.

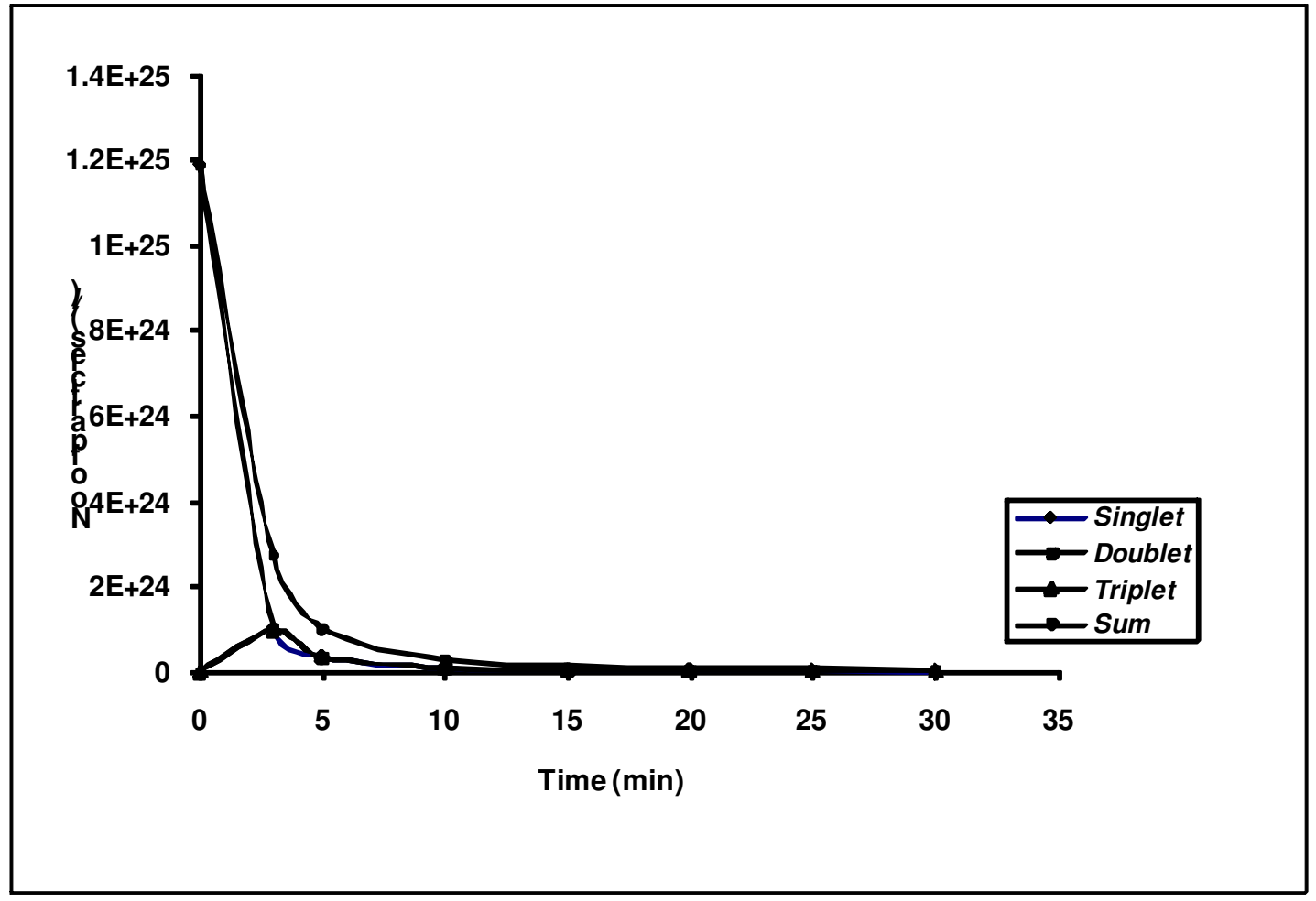

Fig. 2:Temporal particle aggregation profle at minimum half life of $0.0362 \mathrm{~min}$ 


\subsection{Time Course \% Removal Efficiency for Varying pH and CDC Dosages.}

The process efficiency graphically presented in Figures 3-7 are obtained based on the evaluation of equation 8. They depict the variation of efficiency $\mathrm{E}(\%)$ as a function of time and $\mathrm{pH}$ for various CDC dosages of 100, 200, 300, 400 and 500mg/l. It was observed that the trends for all the cases studied are almost identical but with different percentages of efficiency achieved for particular $\mathrm{pH}$ and dosages. This coag-flocculation process was very fast initially with about $99 \%$ efficiency recorded at 3 minutes for all cases. The only exception was recorded at $\mathrm{pH} 2$ where $\mathrm{E}(\%)$ range between 40 and 60 for Figures 4-8. Practically, 99\% of initial SDP load of $19709.20 \mathrm{mg} / 1$ was removed at 3 minutes of coag-flocculation.

The possible explanation for the poor performance at $\mathrm{pH} 2$ could be attributed to hyper protonation and interactions among numerous chemical species present in CWE. This could affect the charge balance following complex reaction likely to have been undergone by the CWE. Arguably, this condition can generate restabalized colloids, causing electrostatic repulsion among the suspended solids. It could also be observed that the CDC recorded satisfactory performance from $\mathrm{pH} 4-10$, but to a different extent. It is reported that CDC performs well in acidic medium because the amine group of CDC is usually protonated by $\mathrm{H}^{+}$ produced from dissociation of $\mathrm{H}_{2} \mathrm{SO}_{4}$. On the other hand, one possible explanation for the good alkaline performance is that alkaline cation can favor delamination of the SDP in suspension, which thereby displays highly accessible surface $[11,26]$. Another important factor that impacted the CDC performance in this study is the CDC dosage. Basically, insufficient dosage or over dosage when confronted with chemical interaction among the chemical species involved in the process could affect the perceived performance of CDC. At unfavorable conditions, excess CDC dosage ensures that excess polymer is adsorbed on the particles surfaces, producing restabalized colloids. The implication is the absence of sites available on the particles surfaces for the formation of inter particle bridge. However, at favorable conditions, excess CDC can lead to particle enmeshment that can instantaneously sweep away the SDP from the suspension. Mechanism of aggregation has possible effects on the influence of dosage on the aggregation process. It has been reported that effective coag-flocculation could be achieved with much lower doses of CDC ,especially when complete charge neutralization is not required and the process guided by combine effects of electrostatic patch and bridging mechanism [11]. 


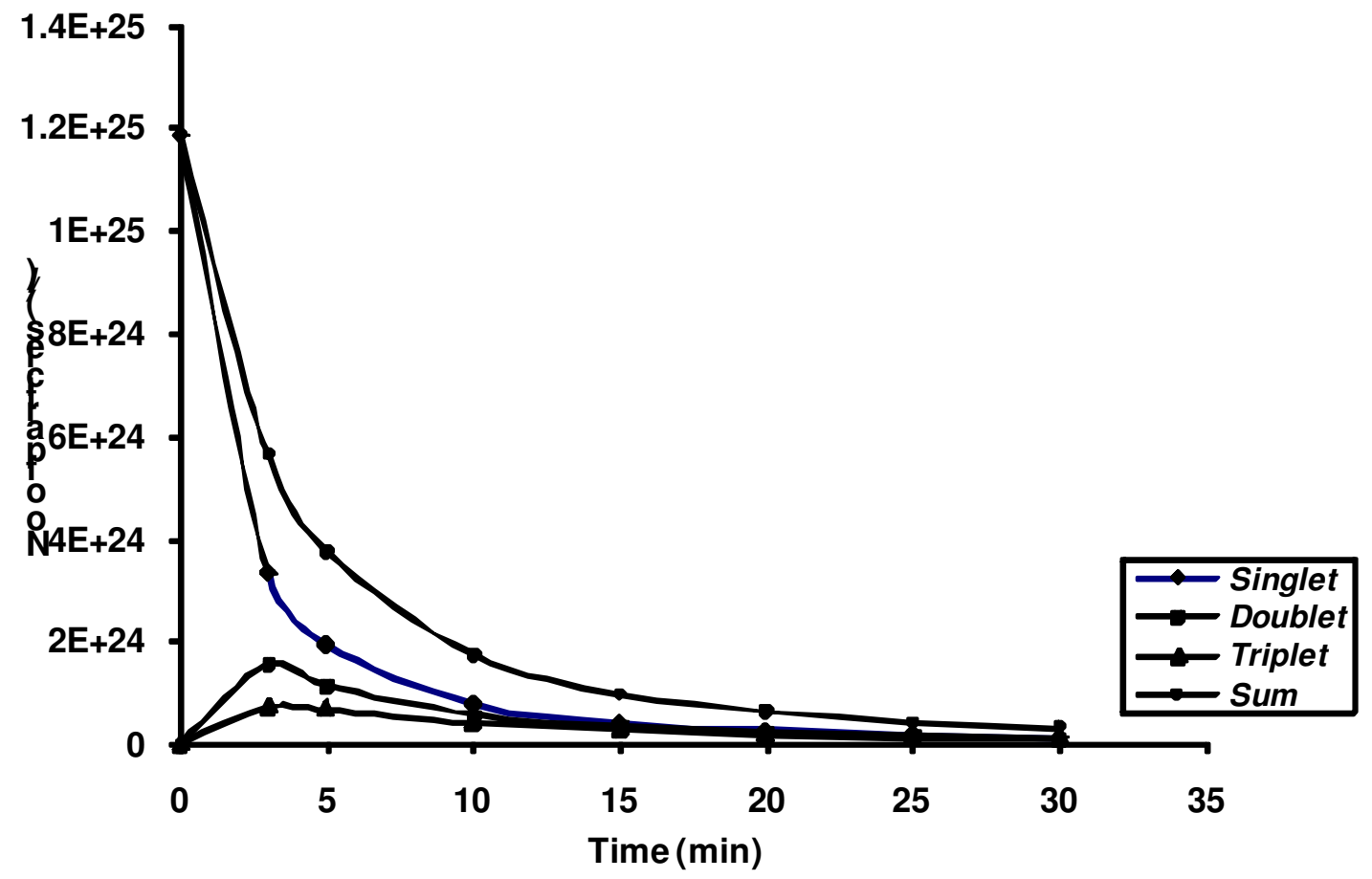

Fig.3:Temporal particle aggregation profile at maximum half life of $3.3825 \mathrm{~min}$

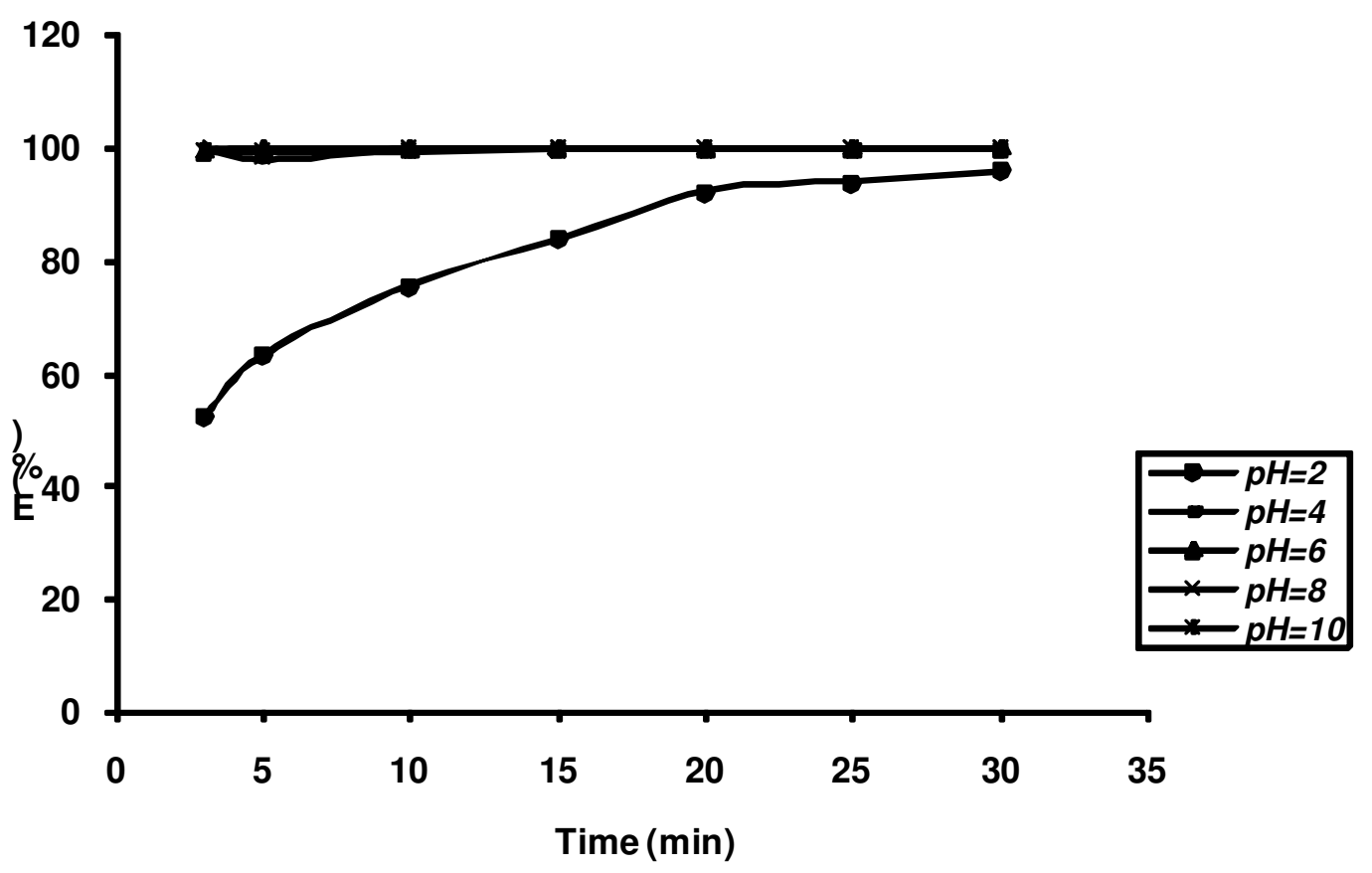

Fig. 4: Temporal coag-flocculation efficiency profile at $100 \mathrm{mg} / \mathrm{l}$ and $\mathrm{pH}$ varying $\mathrm{CWE}$. 


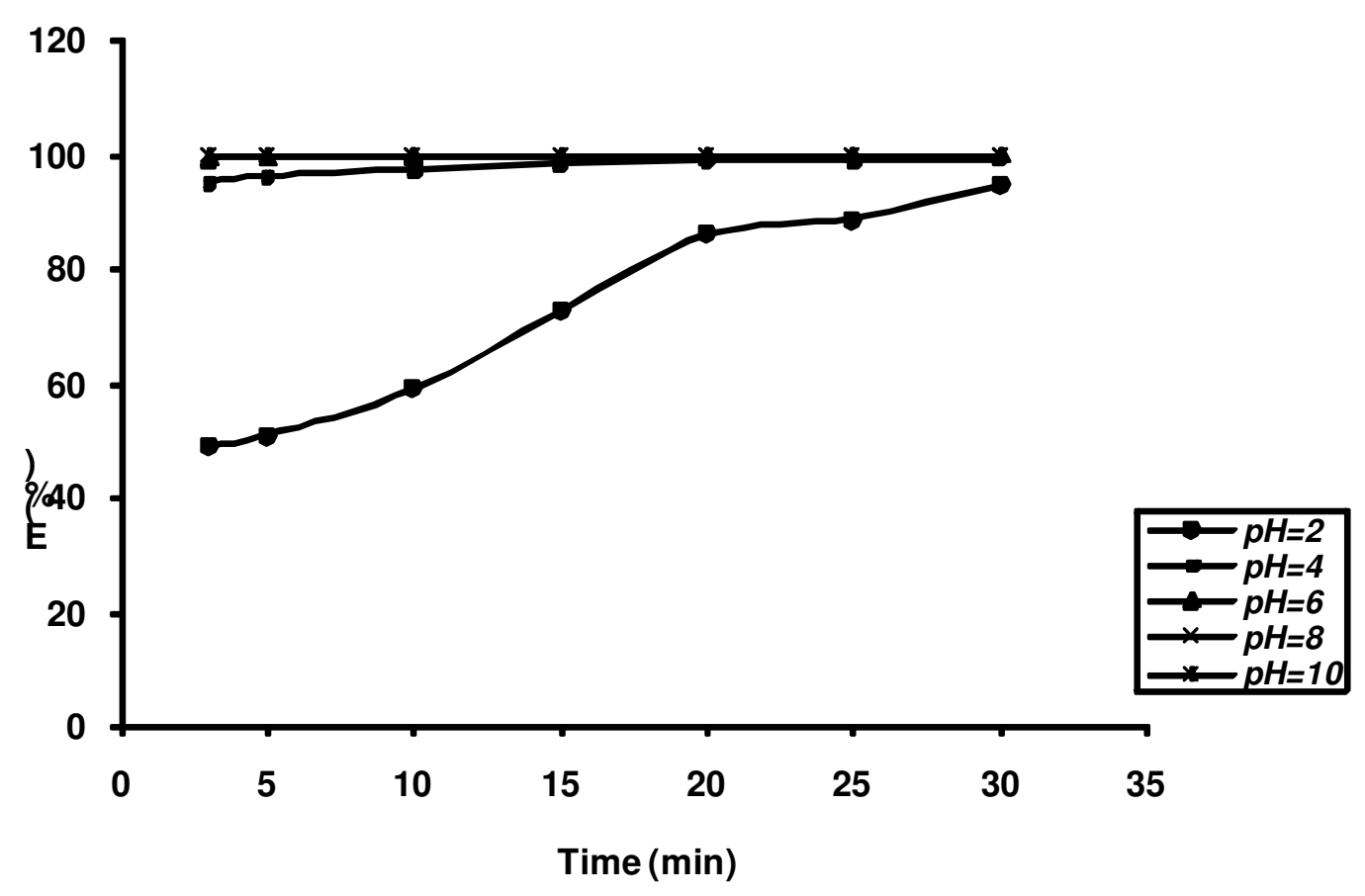

Fig.5: Temporal coag-flocculation efficiency profile at $200 \mathrm{mg} / \mathrm{l}$ and $\mathrm{pH}$ varying $\mathrm{CWE}$

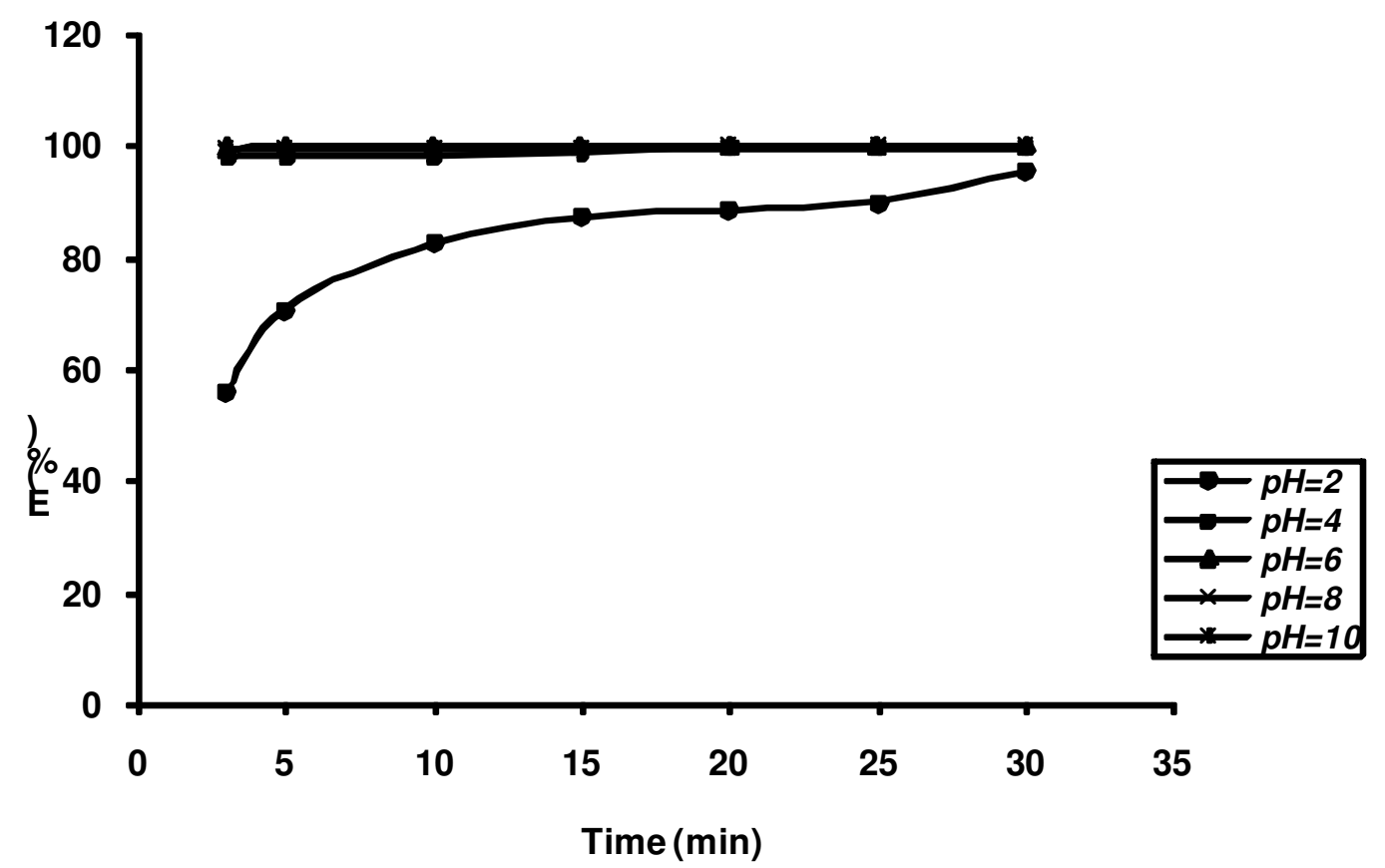

Fig.6:Temporal coag-flocculation efficiency profile at $300 \mathrm{mg} / \mathrm{l}$ and $\mathrm{pH}$ varying $\mathrm{CWE}$. 


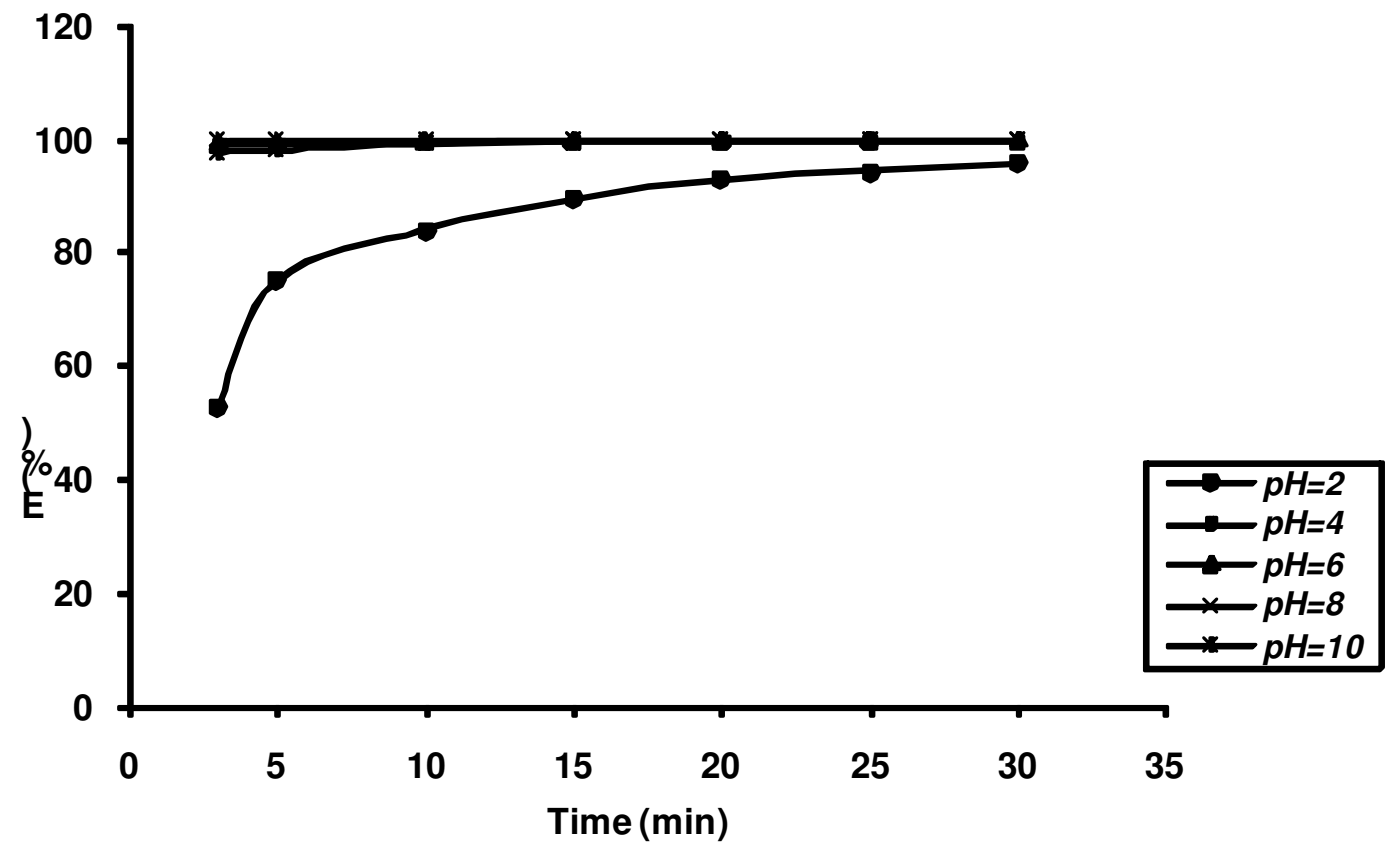

Fig.7 :Temporal coag-flocculation efficiency profile at $400 \mathrm{mg} / \mathrm{l}$ and $\mathrm{pH}$ varying CWE.

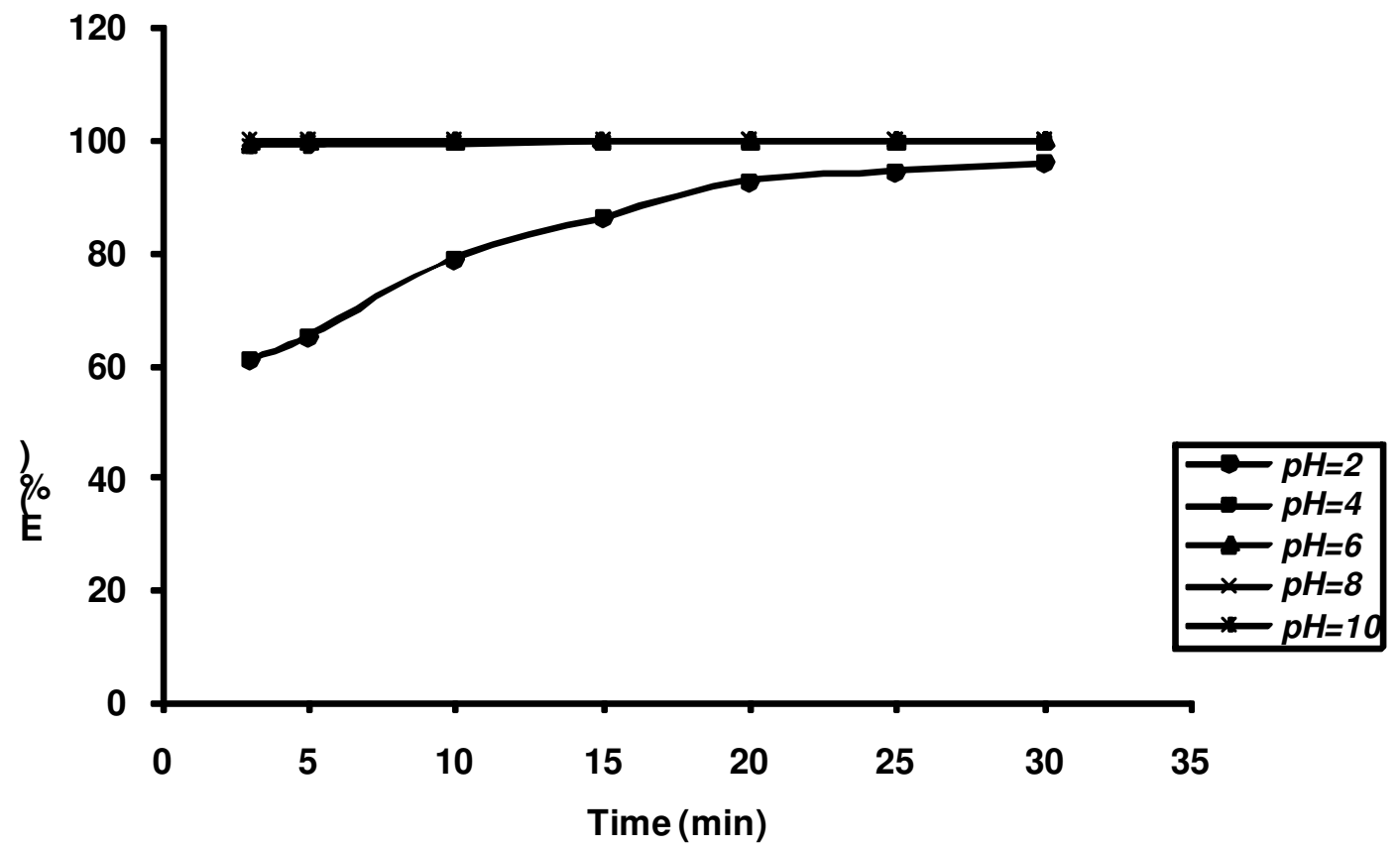

Fig.8: Temporal coag-flocculation efficiency profile at $500 \mathrm{mg} / \mathrm{l}$ and $\mathrm{pH}$ varying CWE. 


\subsection{Comparative Coag-flocculation Performance Between CDC and Alum.}

Figure 9 is the comparative performance chart between CDC and alum at varying $\mathrm{pH}, 100 \mathrm{mg} / \mathrm{l}$ $\mathrm{CDC}$, and 30minutes. The least performance is recorded at $\mathrm{pH}$ 2.This is explained by various reasons adduced earlier in this communication. However, the performance is about $94 \%$ for all the $\mathrm{pH}$ considered at this dosage. Similar results(not shown) were obtained for 200, 300, 400 and $500 \mathrm{mg} / \mathrm{l} \mathrm{CDC}$ dosages. The best performance was recorded at $\mathrm{pH} 8$ and $99.933 \%$ while the least was recorded at $\mathrm{pH} 2$ and $94.7537 \%$. The fact is that CDC compares favorably with alum with advantage of being eco-friendly. Additionally, the use of CDC raises no health concerns, which is one of the major setbacks in the application of alum in water treatment.

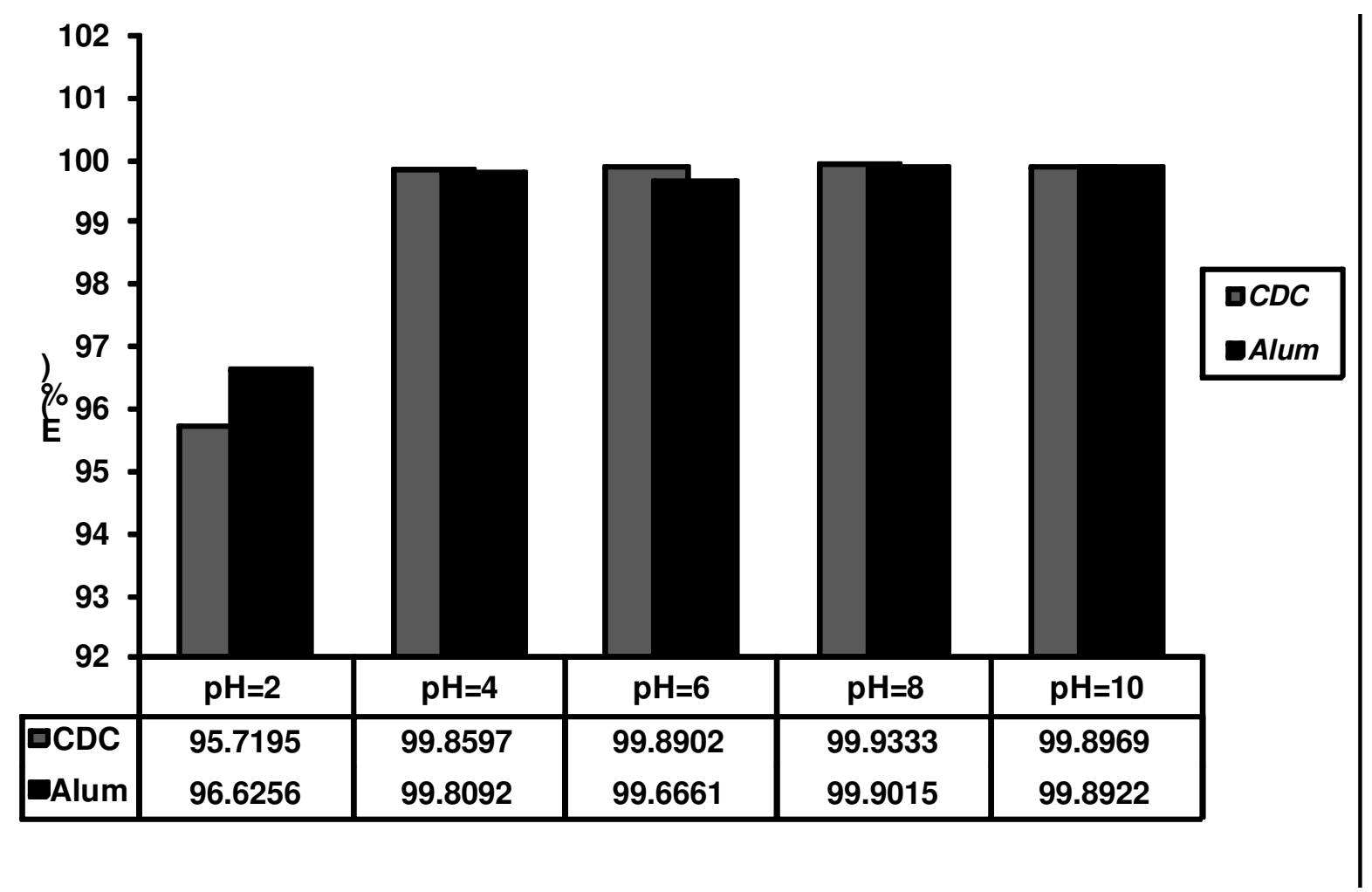

Fig. 9: Representative comparative coag-flocculation performance between Alum and CDC for $100 \mathrm{mg} / \mathrm{l}$ at $30 \mathrm{mins}$.

\section{CONCLUSION}

The high level of efficiency achieved within 30 minutes affirms the prevalence of rapid coagflocculation, hence the dominance of perikinetics in the removal of SDP from CWE by CDC . The efficiency of CDC recorded establishes it at a pilot scale and within the experimental conditions as a veritable treatment agent for the removal of SDP from CWE. The best results were obtained at $\mathrm{pH} 8,100 \mathrm{mg} / \mathrm{l}$ dosage and $99.933 \%$ efficiency. 


\section{REFERENCES}

[1] Menkiti, M.C., 2010. Sequential treatments coal washery and brewery effluents by biocoagflocculation and activated carbon adsorption. Ph.D Thesis. Department of Chemical Engineering, Nnamdi Azikiwe University, Awka, Nigeria.

[2] Ghose, M.K., 2008; Process of recovering resources from coal washery effluent for sustainability, Centre of Mining Environment, Indian School of Mines University, Dhanbad, India.

[3] Menkiti, M.C. and Onukwuli, O.D., 2011a. Coag-flocculation of Mucuna seed coagflocculant (MSC) in coal washery effluent (CWE) using light scattering effects. AICHE Journal. 57 (5) DOI: 10.1002/aic.12665.

[4] Das, B., Prakash, S., Biswall, S.K., and Reddy, P.S.R, 2006; Ssettling characteristics of coal washery tailings using synthetic polyelectrolytes with fine magnetite, The journal of the southern African Institute of mining and metallurgy. 106 :707-712.

[5] Mousas, P.A. and Zouboulis, A.I., 2008. A study on the properties and coagulation behavior of modified inorganic polymeric coagulant-polyferric silicate sulphate (PFSS). Seperation and Purification Technology. 63: 475-483.

[6] Oladoja A.N. and Aliu Y.D., 2009. Snail shell as coagulant aid in the alum precipitation of malachite green from aqua system. Journal of Hazardous Materials. 164 (2-3) : 1496-1502.

[7] Menkiti M.C. and Onukwuli O.D., 2011b. Coag-flocculation studies of Afzelia bella coagulant $(\mathrm{ABC})$ in coal effluent using single and simulated multi angle nephelometry. Journal of Mineral and Material Characterisation and Engineering. 10 (3) : 279-298.

[8] Menkiti M.C. and Onukwuli O.D., 2011c. Single and multi angle nephelometric approach to the study of coag-flocculation of coal effluent medium using Brachystegia eurycoma coagulant. World Journal of Engineerig. 8(1) : 61-76.

[9] Menkiti M.C., Nnaji P.C., Nwoye C.I. and Onukwuli O.D., 2010. Coag-flocculation kinetics and functional parameters response of mucuna coagulant to $\mathrm{pH}$ variation in organic rich coal effluent medium. Journal of Mineral and Material Characterisation and Engineering. 9 (2) : 89-103.

[10] Roberts G.A.F., 1997. Adv. Chitin Sci.II. Proceedings of the $7^{\text {th }}$ International Conference on Chitin and Chitosan, Lyons.

[11] Chatterjee T., Chatterjee S. and Woo S.H., 2009. Enhanced coagulation of bentonite particles in water by a modified chitosan biopolymer. Chemical Engineering Journal. 148: 414-419.

[12] Knorr D., 1984. Use of chitinous polymer in food -a challenge for food research and development. Food Technol. 38 : 85-97.

[13] Fernandez,M. and Fox,P.F;1997;Fractionation of cheese nitrogen using chitosan.Food Chem. 58: 319-322.

[14] Guerrero,L.,Omil F.,Mendez,R., and Lema,J.M;1998;Protein recovery during the overall treatment of wastewaters from fish-meal factories,Bioresource Technology. 63: 221-229. 
[15] Menkiti M.C., Igbokwe P.K., Ugodulunwa F.X.O. and Onukwuli O.D., 2008. Rapid coagulation/flocculation kinetics of coal effluent medium with high organic content using blended and unblended chitin derived coagulant(CDC). Research Journal of Applied Science. 3(4) : 317-323.

[16] Divakaran,R., and Pillai,V.N.S.,2002; Flocculation of river silt using chitosan, Water Resources. 36 : 2414-2418.

[17] Roussy J., Vooren M.V., Dempsey B,A and Guibal E., 2005. Influence of chitosan characteristics on the coagulation and the flocculation of bentonite suspension. Water Resources. 35 : 3247-3258.

[18] Huang,C.P, Chen,S.C and Pan,J.R.S.,2000;Optimal condition for modification of chitosan: A biopolymer for coagulation of colloid particles, Water Resources. 34:1057-1062.

[19] Jin Y., 2005. Use of high resolution photographic technique for studying coagulation/flocculation in water treatment. M.Sc Thesis. University of Saskatchewan, Saskatoon, Canada.

[20] Hunter R .J., 1993. Introduction to Modern Colloid Science. $4^{\text {th }}$ edition. University Press. New York. 33-38, 289-290

[21] Van Zanten J.H. and Elimelech M., 1992. Determination of Rate constants by multi angle light scattering. Journal cof colloid and interface. 154 (1) : 621

[22] Menkiti M.C. and Onukwuli O.D., 2010. Coag-flocculation studies of Moringa oleifera coagulant(MOC) in brewery effluent: Nephelometric approach. Journal of American Science. 6 (12) : 788-806.

[23] Clesceri L.S., Greenberg A. E. and Eaton A.D., 1999. Standard methods for the examinatin of water and waste water. $20^{\text {th }}$ editon. APHA. USA.

[24] Fernadez-Kim S., 2004. Physiochemical and functional properties of crawfish chitosan as affected by different processing protocles. M. Sc Thesis. Department of food Science, Louisiana State University and Agricultural and Mechanical College. USA. 1-99.

[25] AOAC., 1993. Offcial methods of Anal ysis.Association of official analytical chemist. $14^{\text {th }}$ edition.USA.

[26] Assad E., Azzouz A., Nistro D., Ursu A.V., Sajin T., Miron D.N., Monette F., Niquette P. and Hausler R., 2007. Metal removal through synergic coagulation-flocculation using an optimized chitosan-montmorillonite system. Applied Clay Science. 37: 258-274.

[27] Gibbs G., Tobin J.M. and Guibal E., 2003. Sorption of acid green 25 on chitosan: Influence of experimental parameters on uptake kinetics and sorption isotherms. J. Appl. Polym. Sci. 90 : 1073-1080.

[28] Holthof, H., Egelhaaf, S.U, Borkovec, M., Schurtenberger P and Sticher, H (1996); Coagulation Rate Measurement of Colloidal Particles by Simultaneous Static and Dynamic Light Scattering, Langmuir 12:5541

[29] Holthof, H., Schmitt, A., Ferńandez-Barbero, M; Borkovec. M., Cabrerizo-Vilehez, P; Schurtenberger, P and Hidalgo-Alvarez, R ; (1997) Measurement of Absolute Coagulation 
Rate Constants for Colloidal Particles: Comparison of Single and Multiparticle Light Scattering Techniques; Journal of Colloid and Interface Science, 192:463-470

[30] Menkiti M.C., 2007. Studies on the rapid coagulation and flocculation of coal washery effluent: A turbidimetric approach. M.Eng. Thesis. Chemical Engineering Department, Nnamdi Azikiwe University Awka Nigeria. 